\title{
The Regulatory Challenge to Branding: An Interpretation of UK Competition Authority Investigations 1950-2007
}

by

\author{
John K. Ashton \\ Norwich Business School and the ESRC Centre for Competition \\ Policy, University of East Anglia \\ \& \\ Andrew D. Pressey \\ Management School, Lancaster University
}

CCP Working Paper 09-2

\begin{abstract}
This study examines if, and how, branding constitutes an anticompetitive act. These questions are assessed through an examination of UK competition cases undertaken over the period 1950-2007. From this assessment it is observed that branding can facilitate excessive pricing, requires vertical restraints, and can lead to consumer confusion. Competition cases focused on branding issues are demonstrably different from cases without branding concerns and involve larger, often manufacturing, firms, which operate in more concentrated markets. It is concluded that competition law needs to be disseminated more widely amongst business communities. This will require greater prominence for competition policy within business school syllabi and greater reference to business and management theory on the part of competition law agencies would assist the comprehension of business techniques such as branding.
\end{abstract}

December 2008 
JEL Classification Codes: M31, K21, L42.

Keywords: branding, competition law, antitrust

\section{Acknowledgements:}

The support of the Economic and Social Research Council is gratefully acknowledged. Further we would like to thank Catherine Waddams for her helpful comments on an earlier draft of this paper. All errors remain the responsibility of the authors.

\section{Contact details:}

John K. Ashton, ESRC Centre for Competition Policy and Norwich Business School, University of East Anglia, Norwich, NR4 7TJ, UK.

j.ashton@uea.ac.uk

Andrew D. Pressey, Lancaster University Management School, Lancaster University, Lancaster, LA1 4YX, UK.

a.pressey@lancaster.ac.uk 


\section{Introduction}

Can branding constitute an anticompetitive act? If so, are anticompetitive branding cases different from other anticompetitive cases? This study provides answers to these questions by examining how the practice of branding and brand management has been viewed by a European competition authority in the last half century. This is undertaken through the systematic assessment of 423 competition examinations made by the UK competition authorities between 1950 and 2007. These competition cases indicate how a national competition agency subject to both EU competition law $^{1}$ and national law has assessed branding. A testing procedure is then adopted to identify if anticompetitive cases which consider branding issues are different from other non-branding cases.

From this analysis it is reported that branding has a range of anticompetitive features. These include branding as a source of excessive pricing, branding as a vertical restraint, and branding as a process through which choice can be restrained or customer confusion can emerge. These forms of anticompetitive branding activities differ significantly from other anticompetitive actions. Anticompetitive branding activities involve relatively large firms operating in concentrated markets and include a high proportion of manufacturing firms. It is concluded that competition law authorities need to reassess their treatment of branding and managers of particularly large and dominant firms must become aware of the potential for anticompetitive actions when managing brands.

This assessment is important for a range of reasons. Initially, branding is a central business tool in the development and sale of goods and services. Indeed, branding is a long standing business practice with assets developed from branding activity subject to substantial legal recognition and protection (see Gillespie et al. 2002). Understanding the circumstances under which branding is anticompetitive has immediate implications for managers wishing to demonstrate legal compliance. This is an issue of growing importance in light of

\footnotetext{
${ }^{1}$ The terms antitrust law and competition law are broadly comparable. The use of the term 'antitrust law' is associated with the USA and the term 'competition law' is associated with Europe. The UK joined the EC in 1971 and became subject to EU law; before 1971 the UK was subject to UK competition law which operated on lines similar to the USA, if less strict in application of competition principles
} 
the international expansion of competition laws. Competition law has spread internationally in the last 50 years in many forms (Djelic 2002; Hylton and Deng 2007) involving policy and practice of price setting cartels, the competitive assessment of firm mergers and anticompetitive behaviours, with economic and social regulation, one of the three principal forms of business-government interaction (Hillmann et al 1999).

Secondly, while the interface between business and government has been extensively researched (see Hillman et al 2005; Shaffer 1995; Vogel 1996), there has been only limited assessment of the importance of competition law for businesses internationally (Clougherty 2005). Indeed, in some business disciplines competition issues, such as mergers, have only been considered fleetingly (Homburg and Bucerius 2003).

Lastly, this study seeks a clearer comprehension of how brands have been assessed within competitive assessments. As uncertainty in the businessgovernment interface has the potential to create significant transaction costs (Hillman et al 1999), comprehension of the competition law treatment of widely used business practices has an immediate benefit for management and the wider economy.

To examine the links between UK competition law and branding, the study is divided into five sections. Following this introduction, a review of literature examining the intersection between branding and competition law is outlined. In section three we discuss the research aims, data collection methods and forms of assessment. The findings of the study are provided in section four before conclusions are drawn and areas for future research proposed in section five.

\section{Branding and Competition Law}

This section introduces the diverse literature considering the interface between branding as a business activity and competition law. This review considers the rationale of branding, the development and focus of competition law, and the 
historical treatment of branding under competition law. These issues are considered in turn.

\subsection{The Rationale of Branding}

Seen from either the viewpoint of the firm or the consumer (Shocker and Weitz, 1988), branded products and services provide a number of benefits including legal protection (under international trademark law), an identity system and a mechanism to add customer value (de Chernatony and Dall'Olmo Riley, 1997) and may represent a significant (or even the only) form of assets within the company. Brands also fulfil a social role in communicating different values and aspirations of individuals through society and are widely imitated. A successful brand requires significant levels of brand awareness and a positive image distinct from competitors' offerings (Keller, 1998; Krishnan, 1996). Developing a brand to a stage where a customer following will pay a price premium involves substantial investment in advertising and product design often over considerable periods of time. It is unsurprising then, that branding and brand strategy is regarded as one of the most important and long-standing areas of business education and research (Reed 1929) and is widely viewed to be a management priority (Keller and Lehmann 2006)

Despite its importance, branding has the potential to be an anticompetitive action. This situation arises because competition laws and brand management have divergent goals. Competition law at its broadest is concerned with social welfare and the interests of customers. The general aim of competition laws is to protect consumers and curb the influence of powerful sellers to restrict competition and increase prices (Kirkwood and Lande 2008), advance the provision of low-price, high-quality goods and services (Klein 1999), and encourage firms to become rivals (Easterbrook 2008). While competition law attempts to ensure firms operate efficiently and act as rivals, firm interests are generally subservient to the needs of customers (Easterbrook 2008). Specifically, competition law aims to ensure that consumers pay the lowest possible price coupled with the highest quality and suitability of the goods and services which they consume. Indeed, the wider challenge within antitrust or competition law is striking the right balance between encouraging firms to 
innovate and develop new products and services and discouraging the abuse of market power acting against the interest of customers (Carlton 2007).

This view conflicts with developing brands as a mechanism to induce purchase (often at a premium price), command consumer loyalty and deter other companies from entering a market. Hence, the marketing of brands is not altruistic (Firat et al. 1987), but a profit maximisation and differentiation strategy (Dibb et al. 1994), which may conflict with competition laws designed to protect consumers. Despite this conflict, the assessment of brands by competition authorities has attracted limited previous discussion.

\subsection{The Development and Focus of Competition Law}

While managers often understand some concerns of competition law such as fixing prices with competitors (Bush and Gelb 2005), many fail to comprehend the competition law implications of all their business activities. Two areas of confusion are the distinction between having and abusing a monopoly position and the differential standards expected from monopolistic and non-monopolistic firms (Yoffie and Kwak 2001). In particular, the behaviour and actions of firms dominating markets are of interest to competition authorities to prevent the abuse of a monopoly position. Firms which have grown to dominate markets must adjust their behaviours accordingly as monopolists are not allowed to undertake the same scope of activities as smaller firms under competition law (Yoffie and Kwak 2001).

This potential for firms to fall foul of competition law is increased by the spread in competition law throughout the world. Currently, over one hundred nations have antitrust or competition laws (Djelic 2002), accounting for over $80 \%$ of world trade (Crampton and Boudreaux 2004). This international proliferation of competition law has emerged due to growing confidence in the market mechanism (Waller 1997) and the central role of competition within an economy to promote efficiency, innovation and economic development (Baer 1996). Despite the spread of competition laws compliance can be difficult for many firms as national definitions of anticompetitive behaviour vary (Aiginger et al. 2001, Fox 1997, Vickers 2005). These differences often reflect national cultures 
(Dobbin and Dowd 1997) where ".... a nation's competition law will tell you the most about its economic and political system and whether it puts its faith in the commands of government or the operation of the market" (Waller 1997, p.395).

The scope of competition policy considers a range of actions, from cartels and price fixing arrangements, to the examination of the competitive outcomes of mergers and acquisitions, to assessments of competition existing within individual product markets. Regulatory bodies such as the Competition Commission in the UK, the Director General for Competition in the European Union, and the Federal Trade Commission and Antitrust Division of the Department of Justice in the US undertake inquiries of companies and industries perceived to be operating against the public interest or anticompetitively. These regulatory authorities have powers to break up firms, levy substantial fines and in some nations (including EU states), require firms to adapt certain business behaviours.

The penalties for violating competition laws vary internationally. For example, penalties under US antitrust law can be applied to both US and international firms and individuals engaging in US markets. These punishments include firm fines and up to three years imprisonment and/or fines for individuals involved. Cases judged within the US courts are also subject to randomness in the choice of judges, lawyers and consultants (Salop 1993). This results in the fluctuation of penalties for violations which are often severe for actions such as price fixing cartels (Tarullo 2000). In comparison, businesses violating UK competition law ${ }^{2}$ are judged by a panel of 'experts' appointed by a single competition authority, the Competition Commission and its predecessors (the Monopolies and Restrictive Practices Commission [MRPC], the Monopolies Commission [MC] and Monopolies and Mergers Commission [MMC]). Currently, UK firms are liable to fines of $10 \%$ of worldwide turnover and unlimited fines for cartel

\footnotetext{
${ }^{2}$ The Monopolies and Restrictive Practices Commission (MRPC) was established, under the Monopolies and Restrictive Practices Control and Enquiry Act (1948), to challenge and amend these restrictive agreements. Over time, additional competition legislation expanded the form of enquiry to consider the public interest concerns of mergers and situations where dominance or monopoly concerns arose (Monopolies and Mergers Act 1965). The Competition Act (1998) established the Competition Commission as a successor to previous competition law bodies. Competition law is currently undertaken subject to the Enterprise Act (2002)
} 
behaviour. Further, damage claims may also be brought by third parties, such as injured competitors, against the offending firm or firms. Any individual involved in actions breaking the Enterprise Act (2002) may be imprisoned for five years and disqualified from directorships for fifteen years.

The enforcement of competition law also differs internationally. While historically competition law has been most rigorously enforced in the US, EU competition regimes have recently become increasingly stringent. Some commentators have even indicated '... for large enterprises 'antitrust risk' - the risk of violating some competition law provision - is substantially higher in the European Union than anywhere else" (Hylton and Deng 2007, pp.314-315). Merger regulation in the US focuses chiefly on very large mergers with explicit price fixing concerns, while other jurisdictions such as the EU (Waller 2001) address a greater range of concerns.

This last issue of merger referral has wider importance as firms increasingly operate globally. Today, even domestic mergers between firms located in the same country can attract the attention of distinct national competition authorities as firms increasingly operate and distribute goods and services globally. National competition authorities may choose to intervene to limit or block elements of mergers which affect markets in their jurisdiction; a measure more likely in a world of international subsidiaries and global systems of distribution and sales (see Clougherty 2005). Further, competition authorities, within the US and EU, also choose to block mergers outside their territory leading some commentators to correctly claim competition law assessment is no longer constrained by national borders (Fox 1997).

\subsection{The Intersection between Branding and Competition Law}

The literature examining the intersection between branding and competition law can be categorised into three principal themes. Initially, a wider management literature has emerged considering the business-government interface. Secondly, a US legal literature considering the treatment of business offenses under antitrust laws has been established over a number of years. Lastly, discussion as to how managers can accommodate competition law in the 
marketing of products and services has developed. ${ }^{3}$ These themes are considered in turn.

A growing literature has emerged considering the impact of government legislation and policy on firm activities, and, more widely, the governmentbusiness interface and how firms interact with government. While this literature has developed in importance (Clougherty 2005, Hillman et al. 2005, Shaffer 1995, Vogel 1996) the specific treatment of competition or antitrust law has currently been relatively under-researched. Indeed, Clougherty (2005) indicates for merger policy, "The dearth of scholarship concerning the business government interface regarding merger policy is particularly shaming in light of the breadth of management scholarship in the other dimensions of merger and acquisitions" (p.787). This lack of engagement reflects the reluctance among many business academics to engage in policy discussions (Czinkota 2000). Despite being increasingly confronted by a number of legal and regulatory challenges arising from competition law (Bhattacharya and Korshun 2008, Petty 2005), the assessment of business-government interface within competition law is limited.

A US legal literature has developed considering the treatment of business decisions by antitrust law. Within this literature a range of themes are identified including the market power of brands and restrictive agreements to establish brands. An initial competitive concern with brands is the development of a loyal customer following which is often reluctant to purchase alternative products. This brand loyalty reflects the market power of physically comparable branded goods. Subsequently, physical characteristics tests emerged to ascertain the brand as an enduring source of market power linked to the perception of the product (Austin 1967). These early approaches to examining brands have been widely criticised primarily due to the conflicts with trademark laws which acknowledges the separate quality of brands (Austin 1967). This emphasis on physical characteristics does not fully recognise the importance of consumer valuation and brand attributes, including perceived quality, potential goodwill

\footnotetext{
${ }^{3}$ A sizable literature also exists in economics considering the allied topics of product differentiation; introductions to these literatures are provided by Lancaster (1990) and Salop (1993)
} 
and reputation (Leary 2001). Indeed, many US cases have arisen as dominant firms viewed the scope of patent and copyright laws to cover potentially anticompetitive actions (Carrier 2002). This reflects different perceptions of welfare presented under patent and antitrust laws; the former allowing the recovery of front-end costs through restrictive trade practices, the second viewing constraints on trade as unlawful.

More recently, criticism of branding has centred on the distribution of branded goods and services and efforts to establish and support the brand. Restrictive agreements, which include providing prime shelf space for branded goods, requiring a full range of goods are carried by a retailer or even requiring the sole distribution of a brand, have all raised concerns (Waller 2003). A consistent concern raised with this type of case is identifying what legal offense is caused by this form of restrictive agreement. Anticompetitive aspects of the distribution of branded goods has been considered from a range of perspectives in US legal rulings including predatory pricing, as a barrier to entry, and as a vertical restraint (Grimes 1995, Waller 2003). ${ }^{4}$

A further concern raised in US law is the selective distribution of certain branded goods and services. In many industries firms require that their goods are distributed within a certain type of retail environment, providing a particular level and form of service (Leary 2001). Acknowledgement that the form of distribution of branded goods is important has focused on the importance of choice and variety (Averitt and Landes 1997, 2007, Leary 2001). Subsequently, the provision of choice within markets is itself a goal of antitrust law, and different approaches to differentiate goods should be supported.

Lastly, a diverse literature has arisen to address the relationship between marketing and competition laws. ${ }^{5}$ These primarily US contributions (see LeClair

\footnotetext{
${ }^{4} \mathrm{~A}$ wider review of the antitrust issues surrounding category arrangements such as the provision of prime shelf space is provided by Desochers et al. (2003) and the role of vertical restraints in these forms of branding are outlined by Grimes (1995)

${ }^{5}$ It is acknowledged that some goods and services with substantial externalities have attracted specific legal attention. For example, the actions of some tobacco companies when marketing their brands has been questioned (Liberman and Clough 2002), leading to calls for tighter control of the marketing of tobacco brands. These forms of branding regulation are outside the frame of reference for this study which examines antitrust or competition law
} 
et al. 1997, Gundlach and Phillips 2002, Fontenot and Hyman 2004, Sundie et al. 2008) have identified that US antitrust law presents a significant challenge to marketing practice and emphasise the benefits and problems of compliance with antitrust law (Yoffie and Kwak 2001). Limited international work has also developed assessing both individual competition law judgments and remedies (Ashton and Pressey 2004, Ashton and Keasey 2005) and the treatment of marketing within UK competition law judgements (Ashton and Pressey 2008). The current limited research attention afforded to branding and competition law also runs counter to the historical prominence of competition policy discussions within business literatures (e.g. Engle 1936, Nystrom 1936, McNair 1938, Edwards 1950).

In summary, through considering the regulatory comprehension of branding, the assessment of business techniques by competition regulators may be extended. This study therefore extends this past literature through a focused examination of this particular business practice within the context of European competition law. To achieve this, the final reports on UK competition authority judgements are examined to ascertain the extent that branding has been involved within anticompetitive acts. Consequently, the remainder of this study will review the final reports of investigations undertaken by the UK Competition Commission and its predecessors that consider branded goods. As the subsequent sections will demonstrate, a significant proportion of competition examinations have viewed branding as a central element within anticompetitive practices.

\section{Research Aims and Method}

This study aims to ascertain both how and why branding might be considered to be anticompetitive and whether branding cases are treated differently from other types of anticompetitive actions. These questions are examined by assessing how branding, as a business activity, has been viewed by one national competition authority. To achieve these ends UK competition cases are examined as they provide an indication of how a European national competition 
agency has viewed branding. Within this section the data collection procedures are discussed, the classification of branding in this context is considered and approaches to assess the data are presented.

\subsection{Data Collection Procedures}

Publicly available archival data of decisions made by the UK competition authority over the period $1950-2007$ provided the data for the study. These data are assessed following a dual approach building on established academic traditions. Initially, following Posner (1970), the characteristics of competition cases are quantified providing a platform from which forms of uncompetitive behaviour and links to branding practice can be explored. Secondly, the contents of the individual competition reports are examined to assess links between competition law and the marketing of brands. Considering the contents of competition reports, rather than just the report's decision and characteristics, has been advocated by the competition authorities where "... the philosophy of the Monopolies Commission is enshrined in the reports ... You must read these. Each case is different" (past Monopolies and Mergers Commission Chairman Ashton Roskill (1967) reported in Wilks 1999). This approach is also consistent with other assessments of competition authority cases (Ashton and Pressey 2008).

The competition authority reports analysed were drawn from the 528 final reports of investigations issued over the period $1950-2007$ by the Competition Commission and its predecessors (the Monopolies and Restrictive Practices Commission, the Monopolies Commission and Monopolies and Mergers Commission). From these competition investigations, cases reporting on the performance of public utilities, reviews of industry practices or the transfer of ownership of media assets are outside the study aims and are not considered. This decision was made as these investigations pertain to references made outside competition law or consider a review of general behaviours rather than assessment of firms or markets. Only cases considering either competition concerns within a market (termed market cases) and mergers between two or more firms (termed merger cases) are considered in this study. This classification and timing of competition reports is provided in Table 1. 
Overall, 165 market cases and 258 merger cases between 1965 and 2007 met the foregoing criteria and were examined. These cases are classified in terms of their market size or firm turnover, number of market participants, the geographic focus of activity, the form of industry considered and the outcome of the report (see Tables 2 and 3). All cases undertaken by the UK competition authority are considered and the different time periods for market and merger cases reflects the development of UK competition law. ${ }^{6}$

Table 1: Competition Reports issued in the UK 1950-2007

\begin{tabular}{|c|c|c|c|c|c|c|}
\hline $\begin{array}{c}\text { Time } \\
\text { period }\end{array}$ & $\begin{array}{l}\text { Total } \\
\text { cases }\end{array}$ & $\begin{array}{l}\text { Merger } \\
\text { reports }\end{array}$ & $\begin{array}{l}\text { Market } \\
\text { reports }\end{array}$ & $\begin{array}{c}\text { Transfer of } \\
\text { media assets }\end{array}$ & $\begin{array}{l}\text { Utilities and } \\
\text { Associated } \\
\text { reports }\end{array}$ & $\begin{array}{c}\text { Review cases, } \\
\text { other, or not } \\
\text { undertaken }\end{array}$ \\
\hline $1950-54$ & 9 & 0 & 9 & 0 & 0 & 0 \\
\hline $1955-59$ & 14 & 0 & 12 & 0 & 0 & 2 \\
\hline $1960-64$ & 3 & 0 & 3 & 0 & 0 & 0 \\
\hline $1965-69$ & 29 & 10 & 13 & 2 & 0 & 4 \\
\hline $1970-74$ & 26 & 7 & 12 & 4 & 0 & 3 \\
\hline $1975-79$ & 40 & 14 & 24 & 2 & 0 & 0 \\
\hline $1980-84$ & 58 & 23 & 13 & 6 & 14 & 2 \\
\hline $1985-89$ & 81 & 33 & 25 & 6 & 17 & 0 \\
\hline $1990-94$ & 90 & 44 & 30 & 8 & 8 & 0 \\
\hline 1995-99 & 76 & 48 & 12 & 6 & 10 & 0 \\
\hline $2000-07$ & 102 & 79 & 12 & 3 & 8 & 0 \\
\hline Overall & 528 & 258 & 165 & 37 & 57 & 11 \\
\hline
\end{tabular}

Classifications of branding orientation of the competition cases are reported in Tables 2 and 3. No clear definitions exist to determine which of the cases have clear branding implications or not, requiring the authors to devise their own classification method. All 423 reports (165 market cases and 258 merger cases) were examined and classified as branding related when the terms 'branding', 'brands' or associated terms such as 'trademark' or 'product image' were seen to be important for the case. This classification was made if either the firms involved or the competition authorities saw branding or the associated terms as

\footnotetext{
${ }^{6}$ The market investigations were introduced after the Monopolies and Restrictive Practices Control and Enquiry Act (1948) and both mergers and situations where dominance or monopoly concerns arose were introduced in the Monopolies and Mergers Act (1965). All reports are available via the UK Competition Commission Website (www.competition-commission.org.uk)
} 
important in explaining the competition concerns present. All the branding cases were examined independently by two academic judges and the results compared. Any discrepancies between the two judges were considered and reconciled. From this approach three types of branding case were inductively identified and a total of 56 market cases and 31 merger cases were deemed to consider branding issues (see Tables 2 and 3). This classification illuminates the principal approaches adopted by UK competition authorities when assessing the anticompetitive elements of branding. These themes include a) branding as excessive pricing, b) branding as a vertical restraint, and c) branding as a source of consumer confusion and excessive choice (see Tables 2 and 3$)$.

In total, 5 market cases and 8 merger cases which considered branding were defined as other branding cases and not linked to one of these three themes. Within these cases, the firms involved emphasised branding concerns - an interpretation not shared by the competition authority which emphasised predominantly other concerns. These cases chiefly considered food production and large firms occurring throughout the sample period.

Lastly, the differences between the characteristics of the branding cases and non-branding cases are quantified and recorded in Table 4. The testing procedure assumes branding and non-branding cases are derived from independent populations and have population characteristics independent of each other. Two forms of test are used to examine independence between branding and non-branding cases. For variables with parametric data (firm turnover or market size), T-tests are employed to test if branding and nonbranding groups are equal, and for other variables with nominal data, a phi test is used to test for association between branding and non-branding groups. A full listing of unique cases defined as possessing branding issues is provided in Appendices 1 and 2. 
Table 2: Characteristics of Market Cases (totals reported and associated \%'s reported in parentheses)

\begin{tabular}{|c|c|c|c|c|c|c|c|}
\hline Time period & $1950-59$ & $1960-69$ & $1970-79$ & $1980-89$ & $1990-99$ & $2000-07$ & Overall \\
\hline Total number of reports & $21(12.7)$ & $16(9.7)$ & $36(21.8)$ & $38(23.0)$ & $42(25.5)$ & $12(7.3)$ & $165(100)$ \\
\hline Average market size (£m, 2007 prices) & 944.59 & 1490.77 & 1810.98 & 2231.61 & 2523.16 & 15504.00 & 2879.04 \\
\hline Average number of firms & 638.67 & 245.73 & 6.19 & 101.64 & 30.90 & 12.57 & 141.69 \\
\hline \multicolumn{8}{|c|}{ Geographic focus } \\
\hline National & $6(28.6)$ & $9(56.3)$ & $23(63.9)$ & $28(73.7)$ & $33(78.6)$ & $10(83.3)$ & $109(66.1)$ \\
\hline International & $15(71.4)$ & $7(43.8)$ & $13(36.1)$ & $10(26.3)$ & $9(21.4)$ & $2(16.7)$ & $56(33.9)$ \\
\hline \multicolumn{8}{|c|}{ Type of industry } \\
\hline Manufacturing & $18(85.7)$ & $13(81.3)$ & $12(33.3)$ & $13(34.2)$ & $10(23.8)$ & $2(16.7)$ & $68(41.2)$ \\
\hline Services & $1(4.8)$ & $1(6.3)$ & $16(44.4)$ & $16(42.1)$ & $21(50.0)$ & $7(58.3)$ & $62(37.6)$ \\
\hline Distribution & $1(4.8)$ & $0(0)$ & $3(8.3)$ & $6(15.8)$ & $4(9.5)$ & $0(0)$ & $14(8.5)$ \\
\hline Primary production and food & $1(4.8)$ & $2(12.5)$ & $5(13.9)$ & $3(7.9)$ & $7(16.7)$ & $3(25.0)$ & $21(12.7)$ \\
\hline \multicolumn{8}{|c|}{ Competition report remedies } \\
\hline None & $3(14.3)$ & $4(25.0)$ & $8(22.2)$ & $7(18.4)$ & $15(35.7)$ & $1(8.3)$ & $38(23.0)$ \\
\hline Partial behavioural & $2(9.5)$ & $3(18.8)$ & $14(38.9)$ & $13(34.2)$ & $7(16.7)$ & $4(33.3)$ & $43(26.1)$ \\
\hline Complete behavioural & $16(76.2)$ & $9(56.3)$ & $14(38.9)$ & $16(42.1)$ & $15(35.7)$ & $7(58.3)$ & $77(46.7)$ \\
\hline Structural & $0(0)$ & $0(0)$ & $0(0)$ & $2(5.3)$ & $5(11.9)$ & $0(0)$ & $7(4.2)$ \\
\hline \multicolumn{8}{|c|}{ Branding cases (groups are not mutually exclusive and \%'s report the percentage of total cases) } \\
\hline No. of cases considering branding & $7(33.3)$ & $7(43.8)$ & $11(30.6)$ & $10(26.3)$ & $13(31.0)$ & $8(66.6)$ & $56(33.9)$ \\
\hline No. of cases NOT considering branding & $14(66.6)$ & $9(56.3)$ & $25(69.4)$ & $28(73.7)$ & $29(69.0)$ & $4(33.3)$ & $109(66.1)$ \\
\hline Branding cases linked to excessive pricing & $5(23.8)$ & $5(31.3)$ & $5(13.9)$ & $9(23.7)$ & $7(16.7)$ & $7(58.3)$ & $38(23.0)$ \\
\hline Branding cases linked to vertical restraints & $5(23.8)$ & $4(25)$ & $3(8.3)$ & $8(21.1)$ & $6(14.3)$ & $3(25.0)$ & $29(17.6)$ \\
\hline Branding cases linked to choice and confusion & $3(14.3)$ & $1(6.3)$ & $4(11.1)$ & $1(2.6)$ & $5(11.9)$ & $2(16.7)$ & $16(9.7)$ \\
\hline Other branding cases & $0(0)$ & $0(0)$ & $3(8.3)$ & $0(0)$ & $2(4.8)$ & $0(0)$ & $5(3.0)$ \\
\hline
\end{tabular}


Table 3: Characteristics of Merger Cases (totals reported and associated \%'s reported in parentheses)

\begin{tabular}{|c|c|c|c|c|c|c|}
\hline Time period & $1960-69$ & $1970-79$ & $1980-89$ & $1990-99$ & $2000-07$ & Overall \\
\hline Total Number of reports & $10(3.9)$ & $21(8.1)$ & $56(21.7)$ & $92(35.7)$ & $79(30.6)$ & $258(100)$ \\
\hline Average turnover (£m 2007 prices) target firms & 1429.53 & 686.09 & 2123.69 & 520.61 & 1973.91 & 1358.43 \\
\hline Average turnover ( $€ m 2007$ prices) acquiring firms & 3923.31 & 6067.36 & 3323.84 & 2381.44 & 3216.23 & 3147.01 \\
\hline \multicolumn{7}{|c|}{ Geographic focus } \\
\hline National & $8(80.0)$ & $12(57.1)$ & $32(57.1)$ & $53(57.6)$ & $46(58.2)$ & $151(58.5)$ \\
\hline International & $2(20.0)$ & $9(42.9)$ & $24(42.9)$ & $39(42.4)$ & $33(41.8)$ & $107(41.5)$ \\
\hline \multicolumn{7}{|c|}{ Type of industry } \\
\hline Manufacturing & $6(60.0)$ & $13(61.9)$ & $17(30.4)$ & $18(19.6)$ & $20(25.3)$ & $74(28.7)$ \\
\hline Services, finance, and retail & $1(10.0)$ & $4(19.0)$ & $20(35.7)$ & $31(33.7)$ & $38(48.1)$ & $94(36.4)$ \\
\hline Distribution and transport & $1(10.0)$ & $1(4.8)$ & $11(19.6)$ & $27(29.3)$ & $8(10.1)$ & $48(18.6)$ \\
\hline Primary production and food & $2(20.0)$ & $3(14.3)$ & $8(14.3)$ & $16(17.4)$ & $13(16.5)$ & $42(16.3)$ \\
\hline \multicolumn{7}{|c|}{ Competition report remedies } \\
\hline Merger allowed & $6(60.0)$ & $11(52.4)$ & $28(50.0)$ & $42(45.7)$ & $38(48.1)$ & $125(48.4)$ \\
\hline Behavioural remedies & $0(0)$ & $0(0)$ & $6(10.7)$ & $15(16.3)$ & $13(16.5)$ & $34(13.2)$ \\
\hline Partial divestment & $4(40.0)$ & $10(47.6)$ & $21(37.5)$ & $22(23.9)$ & $16(20.3)$ & $73(28.3)$ \\
\hline Merger blocked & $0(0)$ & $0(0)$ & $1(1.8)$ & $13(14.1)$ & $12(15.2)$ & $26(10.1)$ \\
\hline \multicolumn{7}{|c|}{ Branding cases (groups are not mutually exclusive and \%'s report the percentage of total cases) } \\
\hline No. of cases considering branding & $0(0)$ & $1(4.8)$ & $7(12.5)$ & $16(17.4)$ & $7(9.6)$ & $31(12.0)$ \\
\hline No. of cases NOT considering branding & $10(100)$ & $20(95.2)$ & $49(87.5)$ & $76(82.6)$ & $66(90.4)$ & $227(88.0)$ \\
\hline Branding cases linked to excessive pricing & $0(0)$ & $0(0)$ & $2(3.6)$ & $7(7.6)$ & $3(4.1)$ & $12(4.7)$ \\
\hline Branding cases linked to vertical restraints & $0(0)$ & $0(0)$ & $1(1.8)$ & $4(4.3)$ & $1(1.4)$ & $6(2.3)$ \\
\hline Branding cases linked to choice and confusion & $0(0)$ & $0(0)$ & $3(5.4)$ & $7(7.6)$ & $1(1.4)$ & $11(4.3)$ \\
\hline Other branding cases & $0(0)$ & $1(4.8)$ & $2(3.6)$ & $3(3.3)$ & $2(2.7)$ & $8(3.1)$ \\
\hline
\end{tabular}


Table 4: Characteristics of Branding Cases

\begin{tabular}{|c|c|c|c|c|c|c|c|}
\hline Time period Market cases & $\begin{array}{l}\text { All } \\
\text { brandi } \\
\text { ng } \\
\text { cases }\end{array}$ & $\begin{array}{l}\text { Excessive } \\
\text { Pricing } \\
\text { cases }\end{array}$ & $\begin{array}{l}\text { Vertical } \\
\text { Restraint } \\
\text { cases }\end{array}$ & $\begin{array}{l}\text { Choice and } \\
\text { Confusion } \\
\text { cases }\end{array}$ & $\begin{array}{l}\text { Other } \\
\text { brand } \\
\text { cases }\end{array}$ & $\begin{array}{l}\text { Non- } \\
\text { brand } \\
\text { cases }\end{array}$ & $\begin{array}{l}\text { T/Phi } \\
\text { Test }\end{array}$ \\
\hline \multirow{2}{*}{$\begin{array}{l}\text { Number of reports } \\
\text { Average market size (£m } 2007 \\
\text { prices) }\end{array}$} & 56 & 38 & 29 & 16 & 5 & 111 & \\
\hline & 5603 & 6829 & 4608 & 5410 & 1562 & 1331 & $3.208^{*}$ \\
\hline Average Number of Firms & 39.6 & 56.4 & 65.5 & 4.8 & 1.8 & 208.7 & -1.164 \\
\hline \multicolumn{8}{|l|}{ Geographic Focus (\%) } \\
\hline National & 51 & 55.26 & 48.3 & 31.3 & 60.0 & 73.9 & \multirow[b]{2}{*}{$0.231^{*}$} \\
\hline International & 49.1 & 44.74 & 51.7 & 68.8 & 40.0 & 26.1 & \\
\hline \multicolumn{8}{|l|}{ Type of industry (\%) } \\
\hline Manufacturing & 55.4 & 63.2 & 68.9 & 56.3 & 20 & 33.3 & \multirow[b]{4}{*}{$0.289^{\star}$} \\
\hline Services & 19.6 & 21.1 & 3.5 & 31.3 & 20 & 46.9 & \\
\hline Distribution & 7.1 & 5.3 & 13.8 & 0 & 0 & 9.9 & \\
\hline Primary Production and Food & 17.9 & 10.5 & 13.8 & 12.5 & 60 & 9.9 & \\
\hline \multicolumn{8}{|l|}{ Competition report remedies (\%) } \\
\hline None & 25 & 13.2 & 24.1 & 31.2 & 40 & 34.6 & \multirow[b]{4}{*}{0.077} \\
\hline Partial Behavioural & 21.4 & 26.3 & 24.1 & 25 & 0 & 19.2 & \\
\hline Complete Behavioural & 50 & 57.9 & 51.7 & 43.8 & 40 & 38.5 & \\
\hline Structural & 3.6 & 2.6 & 0 & 0 & 20 & 7.7 & \\
\hline Time period Merger cases & $\begin{array}{l}\text { All } \\
\text { Brandi } \\
\text { ng } \\
\text { cases }\end{array}$ & $\begin{array}{l}\text { Excessive } \\
\text { Pricing } \\
\text { cases }\end{array}$ & $\begin{array}{l}\text { Vertical } \\
\text { Restraint } \\
\text { cases }\end{array}$ & $\begin{array}{ll} & \text { Choice } \\
\text { and } & \\
& \text { Confusi } \\
\text { on } & \\
& \text { cases }\end{array}$ & $\begin{array}{l}\text { Other } \\
\text { brand } \\
\text { cases }\end{array}$ & $\begin{array}{l}\text { Non- } \\
\text { brand } \\
\text { Cases }\end{array}$ & $\begin{array}{r}\text { T/P } \\
\text { hi Test }\end{array}$ \\
\hline Number of reports & 31 & 12 & 6 & 11 & 8 & 227 & \\
\hline $\begin{array}{l}\text { Average Turnover } \quad(£ m \quad 2007 \\
\text { prices) Target Firms }\end{array}$ & 1189 & 614 & 2328 & 428 & 2250 & 1389 & 0.169 \\
\hline $\begin{array}{l}\text { Average Turnover (£m } 2007 \\
\text { prices) Acquiring Firms }\end{array}$ & 5080 & 3751 & 4118 & 2486 & 10524 & 2851 & $1.773^{*}$ \\
\hline \multicolumn{8}{|l|}{ Geographic Focus \% } \\
\hline National & 45.2 & 58.3 & 33.3 & 36.4 & 37.5 & 60.4 & \multirow[b]{2}{*}{0.100} \\
\hline International & 54.8 & 41.7 & 66.7 & 63.6 & 62.5 & 39.6 & \\
\hline \multicolumn{8}{|l|}{ Type of industry \% } \\
\hline Manufacturing & 19.4 & 8.3 & 33.3 & 27.3 & 12.5 & 29.9 & \multirow{4}{*}{$0.325^{\star}$} \\
\hline Services, finance, and retail & 25.8 & 25.0 & 16.6 & 18.2 & 37.5 & 37.9 & \\
\hline Distribution and transport & 6.5 & 8.3 & 0 & 0 & 12.5 & 20.3 & \\
\hline Primary Production and Food & 48.4 & 58.3 & 60.0 & 54.5 & 37.5 & 11.9 & \\
\hline \multicolumn{8}{|l|}{ Competition report remedies } \\
\hline Merger Allowed & 38.7 & 25.0 & 50.0 & 27.3 & 50.0 & 49.3 & \multirow[b]{4}{*}{0.108} \\
\hline Behavioural Remedies & 12.9 & 25.0 & 16.67 & 9.1 & 12.5 & 9.7 & \\
\hline Partial Divestment & 9.7 & 16.7 & 0 & 9.1 & 12.5 & 9.7 & \\
\hline Merger Blocked & 38.7 & 33.3 & 33.3 & 54.5 & 25.0 & 38.7 & \\
\hline
\end{tabular}

* denotes statistically significant at 5\%. 


\section{Findings and Discussion}

The findings are presented in two sections. Initially, a description of quantitative characteristics are reported over time in Tables 2 and 3 for market and merger cases, and between types of branding case in Table 4 for both market and merger cases. Secondly, the three themes identified in the assessment of branding by the UK competition authority are discussed. Within this discussion statements drawn from the reports are provided to illuminate how branding has been competitively assessed.

\subsection{Competition Case Characteristics}

Both the number of market cases and the size of markets have increased over time indicating the growing case load of the Competition Commission and its predecessors (see Table 2). The average number of firms considered in the market cases declined over time reflecting the reduction in the number of trade associations considered in recent years. The geographical focus of market cases becomes increasingly national over time. The UK's entry into the EU in 1971 acts as a structural break when UK competition authorities started to align competition law with EU competition laws, with international cases involving EU nations increasingly referred to the Director General for Competition. Over time, more cases involved service and distribution industries rather than manufacturing, reflecting a wider change in the UK economy. The remedies of the market cases indicate an infrequent use of structural remedies and a reducing proportion of cases facing behavioural remedies. For merger cases, merger rejection, behavioural remedies and partial divestment have increased over time as remedies to merger investigations. Lastly, the proportion of market cases involving branding (33.9\% overall) is constant over time and appears to disproportionately involve final market transactions.

Within Table 3 the characteristics of merger cases over time are reported. These cases start in 1966 due to the advent of the Monopolies and Mergers Act (1965) and increase in number over the sample period, indicating the growing number of mergers being referred for competition assessment. The 
size of the assessed firms, judged by overall firm turnover, rises over time. The proportion of national merger cases also increases over time, reflecting the growing reference of international cases to European competition authorities. In common with the market cases and for similar reasons, an increasing proportion of merger cases involving service and distribution industries are investigated. The proportion of merger cases linked to branding rises over time with a consistent proportion of cases falling into each of the three types of anticompetitive assessment (excessive pricing, vertical restraints and choice and confusion). Overall, 12\% of merger cases involved branding. The remedies in merger cases also change over time indicating an increasing use of structural and behavioural remedies, rather than rejection of the merger. Differences between the market and merger cases are evident. The first is that more market cases are linked with branding concerns over the time period examined. Second, market cases appear to be more frequently located in manufacturing whilst merger cases are located in a broader range of industries. Lastly, it appears that the market cases are subject to more adverse findings and subsequent remedies and outcomes than the merger cases.

In Table 4 differences between branding and non-branding cases are indicated. For the market investigations all types of branding cases involved fewer firms and larger markets than cases without branding associations. This indicates the importance of large firms often operating in relatively concentrated markets in market inquiries. The markets associated with anticompetitive branding acts are national rather than international, and occur in certain industries, particularly manufacturing. For the merger cases, fewer differences between branding and non-branding cases are found. The size of the acquiring firm denoted by firm turnover is significantly higher for branding cases. Further, differences exist in the industries of merger cases which consider and do not consider branding issues. Branding cases are more likely to be represented in manufacturing and relatively less likely to appear in service industries. For all cases, including both merger and market reports, the remedies issued by the competition authorities do not differ between 
cases observed to include branding issues, and those cases which do not include branding.

\subsection{Types of Anticompetitive Branding Cases}

Based on the 87 branding cases identified, three forms of competitive assessment are applied. These approaches are discussed in turn and illustrated using excerpts from relevant competition reports.

\subsubsection{Branding as a Barrier to Entry Leading to Excessive Prices}

Some 38 market and 10 merger cases involving excessive pricing facilitated by branding have been investigated by UK competition authorities during the sample period. This concern centres on the perception that building brands through advertising is overly expensive and wasteful. In these cases competition is viewed as being pursued through advertising rather than through price. These cases occurred particularly in the 1960s and 1970s within consumer goods markets (e.g. Household Detergents 1966, Breakfast Cereals 1973, Primary Batteries 1974, Tampons 1980). An example of this form of judgement is provided in the Household Detergents case (1966) which illustrates the generally negative view of brand development taken by the Mergers and Monopolies Commission. In this case, "The main criticisms of the policies of the two leading suppliers are ... that their advertising matter is more concerned with emphasising unprovable qualities and building up a 'brand image' than with informing the public about the practical attributes of the product and how the best use can be made of it". The wider benefits of advertising household detergents are also limited: "because competition between the two companies is concentrated on advertising and promotion, the expenditure of both of them in this field is unduly high" (Household Detergents 1966, p.31).

In these cases advertising is viewed to be a barrier to entry that restricts competition. For example, in the Primary Batteries case (1974) the principal supplier (Ever Ready) had a brand position which limited the degree of possible price competition where "Ever Ready's brand reputation is likely in our view to put other brands at a substantial disadvantage, since consumers 
may well prefer to buy Ever Ready batteries in preference to less well-known imported brands even if the latter are cheaper; indeed the mere fact of being cheaper may make unfamiliar brands suspect and therefore less acceptable" (para 430). These issues also appear in merger cases where in the AlliedLyons PLC and Carlsberg A/S merger (1992) concerns were raised with the level of advertising to build beer brands. In this case, "One important aspect of the situation is the heavy expenditure which brewers incur in advertising lager brands...... Several third parties told us that regional and local brewers found it difficult to compete in the supply of standard lager in the face of heavy advertising by the national brewers or brand owners." (section 8.40).

Overall, what can be described as consistent scepticism is displayed by UK competition authorities towards the process of building brands through advertising and subsequently the high prices of some branded goods. Recurring themes include the perceived lack of price competition by dominant firms with strong brands and the wasteful cost of advertising to build brands. These practices raise concerns as they can act as potential barriers to entry to markets resulting in excessive prices. ${ }^{7}$

\subsubsection{Branding as a Vertical Restraint Leading to Selective Brand Distribution and Supply Restrictions}

Vertical restraints are agreements between different participants within the supply chain and encompass a range of contracts between producers and distributors of goods and services. In total, 29 market cases and 6 merger cases have considered branding as a vertical restraint. Two key themes are identified which relate to the use of vertical restraints. Firstly, restrictions in supply occur following a producer's concern that their goods should be sold in an appropriate environment to reflect the brand's wider 'image' and 'needs'. Secondly, producers issue restrictive agreements to ensure goods and services are distributed by retailers in a manner which gives prominence to

\footnotetext{
${ }^{7}$ This interpretation of branding has also been observed in the US where in the FTC v. Proctor and Gamble Co. (1967) case the ability of Proctor and Gamble to develop brands through advertising was viewed to be a barrier to entry (Waller 2001)
} 
the brand. These issues, which have arisen throughout the sample period, are considered in turn.

A number of UK competition cases outline circumstances where the supply of branded goods is restricted by producers to ensure that they are sold within a specified ambience (e.g. Fine Fragrances 1993) or with associated technical support (e.g. Bicycles 1981; Black and Decker 1989). In cases where technical product support is required by the producer, supply refusal is viewed to be a restriction on competition. For example, in the Black and Decker (1989) case "There is ... a public interest in maintaining and enhancing a competitive and innovative retail environment which provides the consumer with service and a wide choice of goods at reasonable prices" (para. 6.62). Similarly, in the earlier Bicycles (1981) case, the Monopolies and Mergers Commission indicated "If Raleigh [a leading manufacturer] had adopted a different attitude towards modern retailing methods and had been more disposed to deal with some of the retailing chains to whom it has hitherto refused supplies, we wonder whether it might be trading more successfully now" (para. 6.26), and, "... no manufacturer with a branded product that, having ventured into the discount market, had ended up worse than before going in" (para. 4.21).

This negative interpretation of supply refusal is not universally adopted. Cases of 'ambience' justifications for supply refusal are granted greater legitimacy than the provision of technical advice. For example, in the Fine Fragrances (1993) case it was accepted that fragrance houses had to maintain a prestigious brand image, noting that "Fragrances are products bought by consumers for reasons going beyond the strict function of the product. It appears to be the general view that consumers can be induced to try a particular fine fragrance brand as much for the sake of its image as for the scent" (para. 3.11).

The second area of concern for the UK competition authority is the use of restrictive agreements to support the brand. These have emerged in many forms, from full line forcing (Frozen Foodstuffs 1976, Tambrands 1996), 
access to shelf space (Gillette Company and Parker Pen Holdings Limited 1993), and the exclusive supply of a single brand by retailers (e.g. Petrol 1965, Ice Cream and Water Ices 1979, Liquefied Petroleum Gas 1981, Carbonated Drinks 1991, New Cars 1992, Ice Cream 2000, New Cars 2000).

Full line forcing, or the offering of discounts to a retailer to stock an entire range of branded goods, is repeatedly observed. In the case of frozen food supplier Birds Eye, discounts were paid retrospectively to some retailers to stock a range of the firm's brands (Frozen Foodstuffs 1976). This behaviour was a part of the "marketing strategy of the need to secure a satisfactory share of the limited capacity of refrigerated cabinets in retail stores" (ibid., para. 299) by Birds Eye and other major suppliers in the market.

To ensure the exclusive supply of a single brand, a range of approaches have been adopted. In the Petrol (1965) case, retailers received rebates from a dominant supplier in return for “... agreeing to sell the supplier's brand of petrol exclusively" (Petrol 1965, para. 82). Alternatively, supply agreements can involve the creation of exclusive geographic territories for the sale of branded goods such as in the supply of new cars in the UK (New Cars 1992, 2000).

A further exclusivity practice relates to buying agreements. In the Car Parts (1982) case, allegations of exclusive buying requirements imposed by car manufacturers on car dealerships were investigated. It was noted that car manufacturers insisted "on the use of their brand names" (para. 4.50) in component manufacture which prohibited specialist component manufacturers from branding their products. This practice where "the purpose of branding car parts" is "...to ensure exclusivity" (Car Parts 1982, para. 4.48) resulted in the identity of specialist component manufacturers being obscured.

To summarise, the aim of branding restrictive agreements or vertical restraints is to place certain branded goods exclusively in a retailing situation which will enforce the potency of the brand. The competition authority has demonstrated repeatedly that these agreements can limit other firms from entering markets. 
Overall, arrangements for the exclusive supplying and buying of brands are viewed adversely by competition authorities when employed by a dominant firm as they may harmfully influence competition in a market.

\subsubsection{Branding as a Process to Reduce Choice and Cause Customer Confusion}

Overall, 16 market cases and 6 merger cases which consider branding are categorised as viewing choice reduction and customer confusion as key competitive concerns. This type of branding case considers a wide range of behaviours which are associated with the provision of choice to consumers and the potential for product choice and product characteristics to confuse customers. In many cases these inquiries relate to circumstances which overlap with excessive pricing and vertical restraint issues.

Customer choice has long been an important issue within competition assessments and is an item within Competition Commission Guidelines. In many early cases it is acknowledged that the provision of a wide range of goods provides benefits to consumers and is a responsibility of dominant firms. For example in the Chemical Fertilizers (1959) case "The company says, however, that it recognises that size carries responsibility, and that it has sought in recent years...to expand the total market for fertilisers without increasing its own proportion, so that consumers will continue to have a choice of products" (Chemical Fertilizers 1959, para 685). Further, the reduction of choice due to market concentration has been consistently criticised in competition assessments (e.g. Man-Made Cellulosic Fibres 1968, Indirect Electrostatic Reprographic Equipment 1976). In the Man-Made Cellulosic Fibres (1976) case it was reported that due to the actions of the dominant firm, "Customers now have little choice but to accept whatever service Courtaulds offers", as choice, "... was lost when the small producers disappeared from the scene" (Man-Made Cellulosic Fibres 1976, para 197). Further, it has been repeatedly indicated that consumer choice can be reduced, to the disadvantage of customers, through a range of actions. These actions have included product licensing (Video Games 1995), forms of firm 
ownership (Foreign Holidays 1997) and joint selling practices (Extended Warrantees on Domestic Goods 2003).

Despite this emphasis, a number of cases have adopted alternative perspectives indicating anticompetitive effects engendered by consumer choice. In the Primary Batteries (1974) case consumer choice is a barrier to entry where "Ever Ready's comprehensive range is likely to present a difficulty to potential competitors since distributors have the convenience of being able to obtain all their requirements of zinc carbon batteries from Ever Ready and therefore do not need, and may be reluctant to do business with, another supplier". Similarly, in the Cat and Dog Food (1977) case the development of different brand varieties adversely affected the efficiency in distribution where "The frequent introduction of different flavours within each brand and of new brands could operate against the interest of consumers if the demand were artificially created by advertising and if the range of flavours and brands significantly raised costs of manufacture and distribution" (Cat and Dog Food 1977, p.241).

The issue of consumer confusion is also important in branding cases considering pharmaceuticals. Confusion arises due to the recognition that some customers have strong propensities for certain brands. For example, in the Insulin (1952) case the introduction of foreign competition was rejected due to the potential for consumer confusion where “... the United Kingdom market is adequately supplied and the importation of additional brands would only cause confusion" (p.29). Similarly, in the case of Chlordiazeoxide and Diazepam supply (1973) introducing new brands was deemed to cause substantial confusion. In this case, "Doctors become accustomed to prescribing a drug under the brand name by which it has been introduced to them by the innovator. They are not easily persuaded to prescribe generically or to prescribe under a different brand name" (Chlordiazeoxide and Diazepam supply 1973, p.58).

Overall, UK competition authorities indicate that aspects of branding can reduce choice and cause customer confusion. Reduced brand choice is most 
evident when carried out by dominant firms to restrict new market entrants ultimately reducing competition. Apparently contradictory rulings on this issue are identified where high levels of choice have also been considered to be a barrier to entry. Further, in terms of consumer confusion, it is identified that branding in some markets (such as pharmaceuticals) increases brand choice, which is a source of confusion. Indeed this observation as to the relative benefits and ill effects of choice may reflect changing approaches in the presentation of choice to customers (Botti and lyengar 2006).

\section{Conclusions and Implications}

This study has assessed the approaches employed by UK competition law authorities to determine the anticompetitive features of branding. It is observed that branding is viewed to be an anticompetitive concern in a range of circumstances. Branding may facilitate excessive pricing, lead to the creation of vertical restraints, and/or result in consumer confusion. Further, branding cases are different from non-branding cases involving larger, often manufacturing firms and generally more concentrated markets. Given these findings the paucity of research within marketing and management on this issue is surprising as the challenges posed to business by regulatory bodies have not diminished and the capacity for dominant firms to engage in anticompetitive behaviour is substantial. Further, as brand management decisions, such as the range of products a firm decides to sell, where the product is sold, the prices charged and brand image maintained may simultaneously restrict competition in one direction and expand it in another (Kay and Sharpe 1982); it is perhaps unsurprising then that brand strategy has featured so consistently in the investigations undertaken by UK competition authorities.

The three methods through which branding has been considered to be anticompetitive (facilitating excessive pricing, creating vertical restraints and resulting in confusion) can all be criticised. The competition authority's view of advertising as creating barriers to entry is premised on questionable empirical 
evidence (Nagle 1981). Indeed, the assessment of brands relative to an assumed commodity price implicit within these arguments, is complicated by the branding of most goods and services. In a world of brands, comparisons to other branded goods and services appear to be a more plausible approach. Subsequently, more recent legal interpretations (Averitt and Landes 1997, 2007) have indicated the positive elements of branding in developing consumer choice. Further, the role of barriers to entry in competition assessment is increasingly disputed in competition law jurisdictions such as the US (Easterbrook 2008).

The interpretation of branding as a method through which vertical restraints can be imposed may occur for several reasons including maintaining brand image (Lovelock 1991; Good and Evans 2001), disciplining price cutting retailers or to avoid supplying bad risk customers (Howe 1979). This issue presents problems for business both due to the importance of using vertical restraints within business transactions and also the differential international interpretation of this anticompetitive behaviour.

Since the early 1980s, US antitrust agencies have adopted a lenient view of vertical restraints with no vertical restraints being contested between 1981 and 1992 (Comanor and Rey 1997). Although this stance has varied depending on political administration (Lafontaine and Slade 2005), US authorities have generally viewed vertical restraints as lawful. ${ }^{8}$ To violate current US antitrust law a vertical restraint must limit output and raise prices rather than merely blocking competitors (Fox 1997, p.10). In particular, issues of distribution are viewed more liberally in the US where the emphasis in investigation is placed firmly on horizontal rather than vertical restraints (Priest 2008).

In comparison, UK and EU competition agencies demonstrate a less tolerant attitude towards vertical restraints that reduce trade both within and between nations. Indeed, Lafontaine and Slade (2005, p.2) suggest there is "perhaps

\footnotetext{
${ }^{8}$ Historically the investigation of vertical restraints in the US and the EU has been similar and even based on the same rule of reason (Maher 2000)
} 
no aspect of competition policy that is as controversial or has been as inconsistent over time and across jurisdictions as policy towards restraints". Dobson and Waterson (1996, p.50) echo this view noting divergent 'underlying philosophies' towards vertical restraints in US and UK/EU competition policy. Currently there is no formal US policy governing vertical restraints (Lafontaine and Slade 2005, p.10), while the EU pursues “... a blanket prohibition on vertical agreements that restrict competition" (Lafontaine and Slade 2005, p.11). These differences may present challenges for larger US firms working in European markets.

Lastly, in considering cases which examine choice and consumer confusion, it appears that major inconsistencies exist in the interpretation of this issue for cases occurring in different markets, such as pharmaceuticals. This uneven application of competition law both increases regulatory uncertainty and provides opportunities for firms in some nations to challenge regulatory outcomes (Hillman et al. 1999). Both developing a more consistent application of concerns in the provision of choice and greater comprehension of the costs and benefits of providing choice through branded products are important. It is further acknowledged that this factor is appreciated within contemporary guidelines for merger activity issued in the EU and the US (see EU 2004 and FTC 2006), which explicitly consider the growing importance of product choice and variety in post merger situations.

Against the foregoing, there is a number of ways in which competition policy concerns and uncertainties may be reduced for firms and managers. These include greater efforts in the demonstration of compliance, a greater recognition of business and management theory within the competitive assessment of markets and firms, and the potential for influencing policy decisions.

It is proposed that managers need to be cognisant of competition law. If managers are uninformed of competition law they may unwittingly and unknowingly fall foul of such law and guidelines particularly when firms' brands command a dominant market share (Bush and Gelb 2005). This 
position is compounded as activities such as marketing and brand management have developed a 'boundary-spanning role' in many organisations (Wilkie and Moore 1999). This position provides managers with ample opportunity to violate competition laws and engage in anticompetitive behaviours. Consequently, business objectives should be created that are cognisant with the rules for competitive behaviour (LeClair 2000). Methods to ensure such compliance are diverse yet could include action learning approaches, random competition law audits and even the use of competition lawyers to cross-examine the actions of managers (Yoffie and Kwak 2001). Most importantly large and dominant firms should alter their business culture to accommodate the demands of competition law and minimise the potential for investigation by competition authorities.

More widely, it has long been recognised that business theory has been systematically ignored and devalued within competition law assessments (Waller 2003). This historical endowment has emerged due to the development of competition laws in the 1930s in the US, and in the late 1940s and 1950s within Europe. During this period business theory was only emerging as an academic discipline and confidence in this subject was limited. In comparison, greater trust in economics existed, leading to its adoption in the discourse of competition law (Waller 2001). Subsequently, international competition laws emphasise economic explanations and are less informed by business theory (Waller 2001); a process continued to the present day (Priest 2008). This has lead to assessments focusing on the prices and efficiencies of firms rather than the actual strategies adopted by firms. This may have led to the often challenging interpretations of business techniques, such as those observed in this study.

Lastly, many previous management studies have assessed the potential to influence regulatory policy. It is increasingly acknowledged that large firms take relationships with government very seriously (see Shaffer 1995) and have developed a range of techniques to engage with government. These include developing political connections and appointments within regulators (Hillman et al. 1999), and the targeting of resources to political campaign 
contributions (Vanden Bergh and Holburn 2007) to assist firm performance. These approaches are premised on regulatory systems which recruit personnel from industry and subject to close political oversight. The potential to influence competition policy in the UK may be relatively limited as the UK Competition Commission increasingly recruit from academia and legal professions rather than business (Wilks 1999) and possess an independent status.

Against this background, it is proposed that building stronger links between competition law enforcement and investigation agencies and business theory would be a positive step. Competition authorities have a lot to learn from understanding business practices developed within business schools. Equally, as marketing develops as a professional discipline and recognises its place within society (Hunt 2007) greater emphasis must be placed on issues of legal compliance and potentially unlawful actions, a process requiring a greater emphasis on teaching competition law within business schools today (Foer 2003). 


\section{References}

Aiginger, K., McCabe, M., Meueller, D. C. and Weiss, C. (2001), "Do American and European Industrial Organization Economists Differ?" Review of Industrial Organization, vol.19, no.4, pp.283-405.

Ashton J. K. and K. Keasey, (2005) "Competition and the Provision of Banking Services to UK SMEs", Small Business Economics, vol.24, no.5. pp.477-485.

Ashton J. K. and A. D. Pressey, (2004). "The Regulatory Challenge to Relationship Marketing in UK Banking", The International Journal of Bank Marketing, vol. 22 no.6, pp.453-464.

Ashton J. K. and Pressey, A. D. (2008). "Regulatory Perception of Marketing: Interpreting UK Competition Authority Investigations from 1950 to 2005", Journal of Public Policy and Marketing, vol.27, no.2, pp. 156164.

Austin, A. D. (1967). "Product Identity and Branding under the RobinsonPatman Act: Is the FTC's Approach Consistent with the Realities of the Marketplace, Villanova Law Review, vol.12, Winter, pp.251-271.

Averitt, N. W. and Lande, R. H. (1997). "Consumer Sovereignty: A Unified Theory of Antitrust and Consumer Protection Law", Antitrust Law Journal, vol. 74, pp.176-264.

Averitt, N. W. and Lande, R. H. (2007). "Using the "Consumer Choice" Approach to Antitrust Law", Antitrust Law Journal, vol.65, pp. 713-756.

Baer, W. J. (1996). "Surf's Up: Antitrust Enforcement and Consumer Interest in a Merger Wave", The Journal of Consumer Affairs, vol. 30, no. 2, pp.292-321.

Bhattacharya, C. B. and Korschun, D. (2008). "Stakeholder Marketing: Beyond the Four Ps and the Customer", Journal of Public Policy and Marketing, vol.27, no.1, pp.113-116.

Botti, S. and lyengar, S. S. (2006). "The Dark Side of Choice: When Choice Impairs Social Welfare", Journal of Public Policy and Marketing, vol.25, no.1, pp.26-38.

Bush, D. and Gelb, B. D. (2005). "When Marketing Practices Raise Antitrust Concerns", MIT Sloan Management Review, vol.46, no.4, Summer, pp.73-81. 
Carrier, M. A. (2002). "Unravelling the Patent-Antitrust Paradox", University of Pennsylvania Law Review, vol.150, no.3, pp.761-854.

Carlton, D. W. (2007). "Does Antitrust Need to be Modernized?", Journal of Economic Perspectives, vol.21, no.3, pp.155-176.

Clougherty, J. A. (2005). "Antitrust Holdup Source: Cross-National Institutional Variation and Corporate Political Strategy Implications for Domestic Mergers in a Global Context", Strategic Management Journal, vol.26, pp.769-790.

Comanor, W. S. and Rey, P. (1997), "Competition Policy towards Vertical Restraints in Europe and the United States", Empirica, vol.24 (March), pp.37-52.

Crampton, E. P. and Boudreaux D. J. (2004). "Does cyberspace need antitrust?" Industrial Organization, 0401001, EconWPA.

Czinkota, M. R. (2000). "The Policy Gap in International Marketing”, Journal of International Marketing, vol.8, no.1, pp.99-111.

de Chernatony, L. and F. Dall'Olmo Riley (1997) "The chasm between managers' and consumers' views of brands: the experts' perspectives", Journal of Strategic Marketing, vol.5, no.2, pp.89-104.

Djelic. M. L. (2002). "Does Europe mean Americanization? The Case of Competition" Competition and Change, vol.6, no.3, pp.223-250.

Dibb, S., Simkin L., Pride, W. and Ferrell, O. C. (1994). Marketing Concepts and Strategies, Houghton Mifflin: Boston.

Dobbin, F. and Dowd, T. (1997). "How Policy Shapes Competition: Early railroad founding in Massachusetts", Administrative Science Quarterly, vol.42, pp.501-529.

Dobson, P. W. and Waterson, M. (1996), "Vertical Restraints and Competition Policy," Office of Fair Trading Research Papers, no.12 (December), London.

Easterbrook, F. H. (2008). "The Chicago School and Exclusionary Conduct", Harvard Journal of Public Policy and Law, vol.31, no.12, pp.439-447.

Edwards, C. D. (1950). "Trends in the Enforcement of the Antimonopoly Laws", Journal of Marketing, vol.15, no.5, pp.657- 665.

Engle, N. H. (1936). "Implications of the Robinson-Patman Act for Marketing", Journal of Marketing, vol. 1, no. 2, pp.75-81. 
European Union, (2004). Guidelines on the assessment of horizontal mergers under the Council regulation on the control of concentration between undertakings. Official Journal of the European Union, C 31/03.

Federal Trade Commission and Department of Justice (2006). Commentary of the Horizontal Merger Guidelines. March, Washington.

Firat A. F. Dholakia N. and Bagozzi R. P. (1987). Philosophical and Radical Thought in Marketing, Lexington Books: Lexington Massachusetts.

Foer, A. A. (2003). The Third Leg of the Antitrust Stool: What the Business Schools have to Offer to Antitrust", New York Law School Review, vol.47, pp.21-49

Fontenot, R. J. and Hyman, M. R. (2004). "The Antitrust Implications of Relationship Marketing", Journal of Business Research, vol.57, no.11, pp.1211-1221.

Fox E. M. (1997). "Towards World Antitrust and Market Access", The American Journal of International Law, vol. 91, no.1, pp.1-25.

Good, D. J. and Evans, K. R. (2001), "Relationship Unrest - A Strategic Perspective for Business-to-Business Marketers," European Journal of Marketing, vol.35, no.5/6, pp.549-565.

Gillespie, K., Kishore, K. and Jarvis, S. (2002). Protecting Global Brands: Towards a Global Norm", Journal of International Marketing, vol.10, no.2, pp.112.

Grimes, W. S. (1995). "Brand Marketing, Intrabrand Competition, and the Multibrand Retailer: The Antitrust Law of Vertical Restraints, Antitrust Law Journal, vol.64, pp.83-136.

Gundlach, G. T. and Phillips, J. M. (2002). "Marketing in Antitrust: Contributions and Challenges", Journal of Public Policy and Marketing, vol.21, no.2, pp.250-253.

Hillman, A. J., Zardkoohi, A. and Bierman, L. (1999). "Corporate Political Strategies and Firm Performance: Indications of Firm-Specific Benefits from Personal Service in the US Government", Strategic Management Journal, vol.20, pp.67-81.

Homburg, C. and Bucerius, M. (2005). "A Marketing Perspective on Mergers and Acquisitions: How Marketing Integration Affects Postmerger Performance", Journal of Marketing, vol.69, (January), pp.95-113. 
Howe, M. (1979), "Pickering on Recommended Prices: A Comment on his Paper", Journal of Consumer Policy, vol.3, March, pp.81-85.

Hunt, S. D. (2007). "A Responsibilities Framework for Marketing as a Professional Discipline", Journal of Public Policy and Marketing, vol.26, no.2, pp.277-283.

Hylton, K. N. and Deng, F. (2007), "Antitrust Around the World: An Empirical Analysis of the Scope of Competition Laws and their Effects," Antitrust Law Journal, vol.74, no.2, pp.271-341.

Kay, J. A., and Sharpe, T. A. E., (1982). "The Anti-Competitive Practice", Fiscal Studies, vol.3, no.3, pp.191-198.

Keller, K. L. (1998). Strategic Brand Management, Prentice-Hall, Upper Saddle River: New Jersey.

Keller, K. L. and Lehmann, D. R. (2006). "Brands and branding: research findings and future priorities", Marketing Science, vol.25, no.6, pp.740759.

Kirkwood, J. B. And Lande, R. H. (2008). "The fundamental goal of antitrust: protecting consumers, not increasing efficiency", Social Science Research Network Working Paper Series, March 18th.

Klein, J. I. (1999). "Antitrust enforcement and the consumer", US Department of Justice, Washington (DC), [http://www.usdoj.gov/atr/public/div stats/1638.htm].

Krishnan, H. S. (1996). "Characteristics of memory associations: a consumerbased brand equity perspective", International Journal of Research in Marketing, vol.13, no.4, pp. 389-405

Lafontaine, F. and Slade, M. (2005), "Exclusive Contracts and Vertical Restraints: Empirical Evidence and Public Policy," Advances in the Economics of Competition Law Conference (June), Rome, Italy.

Lancaster, K. (1990). "The Economics of Product Variety: A Survey", Marketing Science, vol.9, no.3, pp.189-206.

Leary, T. B. (2001). "The Significance of Variety in Antitrust Analysis", Antitrust Law Journal, vol.68, pp.1007-1022.

LeClair, D. T., Ferrell, O. C. and Ferrell, L. (1997). "Federal Sentencing Guidelines for Organizations: Legal, Ethical and Public Policy Issues for 
International Marketing, Journal of Public Policy and Marketing, vol.16, no.1, pp.26-37.

LeClair, D. T. (2000). "Marketing planning and the policy environment in the European Union", International Marketing Review, vol.17, no.3, pp.193215.

Lovelock, C. J. (1991), Services Marketing, Prentice Hall: New Jersey.

Maher, I. (2000), "Re-imaging the Story of European Competition Law," Oxford Journal of Legal Studies, vol.20 (Spring), pp.155-166.

McNair, M. P. (1938). "Fair Trade Legislation and the Retailer", Journal of Marketing, vol.2 no.4, pp.295-300.

Nagle, T. T. (1981). "Do Advertising-Profitability Studies Really Show That Advertising Creates a Barrier to Entry", Journal of Law and Economics, vol.24, pp.333-349.

Nystrom, P. H. (1936). "Legislative Trends of Interest to Students of Marketing", Journal of Marketing, vol.1, no.2, pp.154-155.

Petty R. D. (2005). "Societal Regulation of the Marketing Function: Does the Patchwork Create a Quilt", Journal of Public Policy and Marketing, vol.24, no.1, pp.63-74.

Posner, R. A. (1970). "A Statistical Study of Antitrust Enforcement", Journal of Law and Economics, vol.13, pp.365-419.

Priest, G. L. (2008). "The Abiding Influence of the Antitrust Paradox", Harvard Journal of Public Policy and Law, vol.31, no.12, pp.455-463.

Reed, V. D. (1929). Planned Marketing, New York: The Ronald Press.

Salop, S. C. (1993). "Vertical Restraints Law: Has Economics Mattered?", The American Economic Review, vol.783, no.2, pp.168-172.

Shaffer, B. (1995). "Firm-level Responses to Government Regulation: Theoretical and Research Approaches", Journal of Management, vol.21, no.3, pp.495-514.

Shocker, A. and Weitz, B. (1988). "A perspective on brand equity principles and issues", Report Number 88-104, Marketing Science Institute, Cambridge, Massachusetts.

Sundie, J. M., Gelb, B. D. and Bush, D. (2008). "Economic Reality Versus Consumer Perceptions of Monopoly", Journal of Public Policy and Marketing, vol.27, no.2, pp.178-181. 
Tarullo, D. K. (2000), "Norms and Institutions in Global Competition Policy," American Journal of International Law, vol.94, July, pp.478-504.

Vanden Bergh, R. G. and Holburn, G. L. F. (2006). "Targeting Corporate Political Strategy: Theory and Evidence from the U.S. Accounting Industry", Business and Politics, vol.9, no.2, pp.1-31.

Vickers, J. (2005), "Abuse of Market Power," Economic Journal, vol.115 (June), F244-F261.

Vogel, D. J. (1996). "The Study of Business and Politics", Californian Management Review, vol.38, no.3, Spring, pp.146-165.

Waller, S. W. (1997). "The Internationalisation of Antitrust Enforcement," Boston University Law Review, vol.77, April), pp.343-397.

Waller, S. W. (2003). "The use of business theory in Antitrust Litigation", New York Law School Law Review, vol.47, pp.119-129.

Waller, S. W. (2001). "The Language of Law and the Language of Business", Case Western Reserve Law Review, vol.52, no.283, pp.283-338.

Wilkie, W. L and E. S. Moore, (1999). "Marketing's Contribution to Society", Journal of Marketing, vol.63, Special Issue, pp.198-218.

Wilks, S. (1999). In the Public Interest. Competition Policy and the Monopolies and Mergers Commission, Manchester University Press, Manchester, UK.

Yoffie, D. B. and Kwak, M. (2001). Playing by the Rules: How Intel Avoids Antitrust Litigation", Harvard Business Review, vol.69, no.6 June, pp.119-122. 
Appendix 1: Market cases citing branding

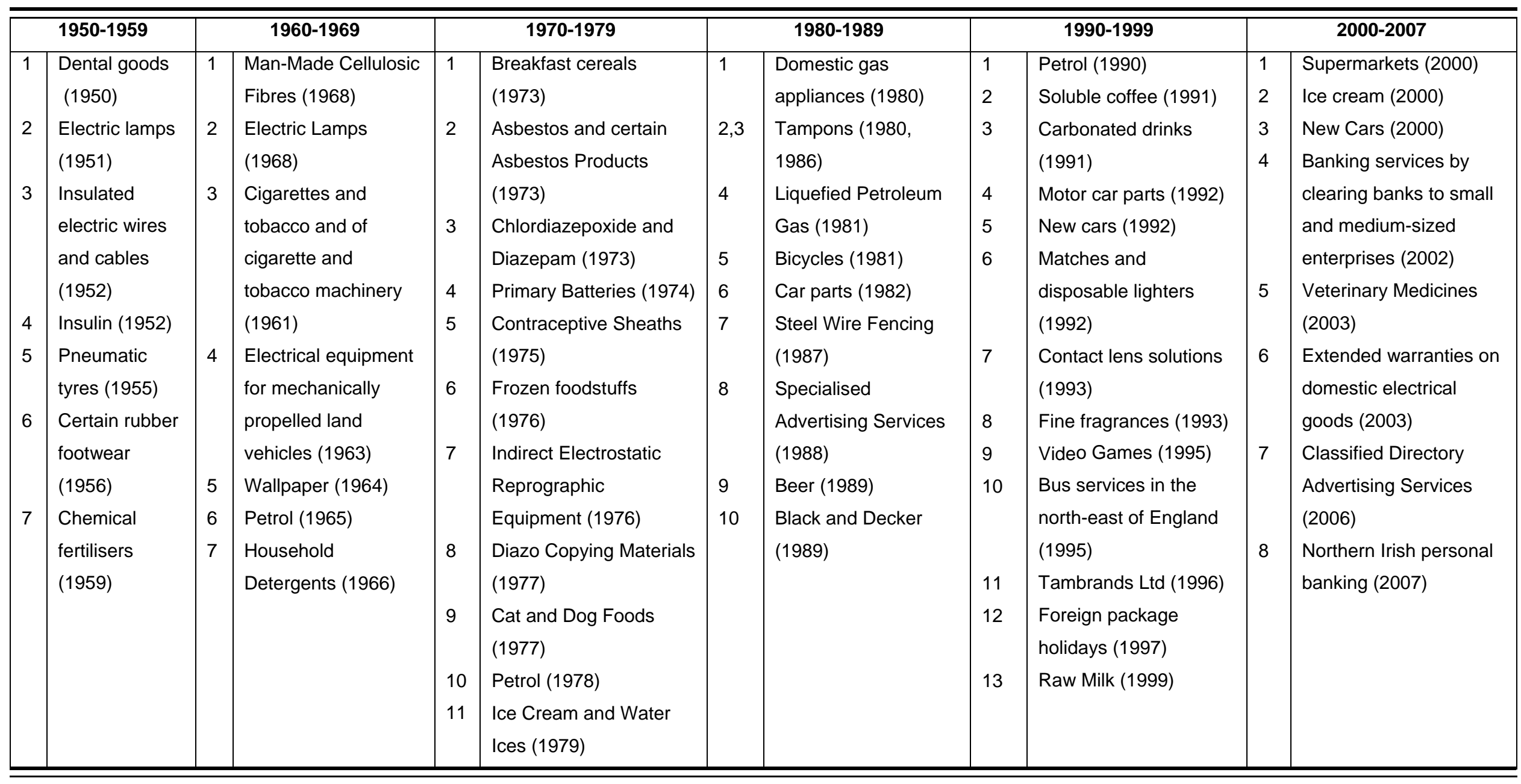




\section{Appendix 2: Merger cases citing branding}

\begin{tabular}{|c|c|c|c|c|c|c|c|}
\hline \multicolumn{2}{|r|}{$1970-1979$} & \multicolumn{2}{|r|}{$1980-1989$} & \multicolumn{2}{|r|}{ 1990-1999 } & \multicolumn{2}{|r|}{$2000-2007$} \\
\hline 1 & $\begin{array}{l}\text { British } \\
\text { Petroleum } \\
\text { Limited and } \\
\text { Century Oils } \\
\text { Group } \\
\text { Limited } \\
\text { (1977) }\end{array}$ & 1 & $\begin{array}{l}\text { Hiram Walker-Gooderham \& Worts } \\
\text { Limited and The Highland Distilleries } \\
\text { Company Limited (1980) } \\
\text { Nabisco Brands Inc and Huntley \& } \\
\text { Palmer Foods PLC (1982) } \\
\text { Scottish \& Newcastle Breweries PLC } \\
\text { and Matthew Brown PLC (1985) } \\
\text { Elders IXL Ltd and Allied-Lyons PLC } \\
\text { (1986) } \\
\text { Yale \& Valor plc and Myson Group } \\
\text { plc (1989) } \\
\text { Grand Metropolitan plc and William } \\
\text { Hill Organisation Limited (1989) } \\
\text { Elders IXL and Scottish \& Newcastle } \\
\text { Breweries PLC (1989) }\end{array}$ & $\begin{array}{l}1 \\
2 \\
3 \\
4 \\
5 \\
6 \\
7 \\
8 \\
9 \\
10 \\
11 \\
12\end{array}$ & $\begin{array}{l}\text { Atlas Copco AB and Desoutter Brother (Holdings) plc (1990) } \\
\text { Ransomes plc and Westwood Engineering Ltd and Laser } \\
\text { Lawnmowers Ltd (1990) } \\
\text { Amoco Corporation and Societe Nationale Elf Aquitaine (1991) } \\
\text { Morgan Crucible Company plc and Manville Corporation (1991) } \\
\text { Kemira Oy and Imperial Chemical Industries PLC (1991) } \\
\text { Lloyds Chemists plc/Macarthy PLC (1992) } \\
\text { Sara Lee Corporation and Reckitt \& Colman plc (1992) } \\
\text { Allied-Lyons PLC and Carlsberg A/S (1992) } \\
\text { Gillette Company and Parker Pen Holdings Limited (1993) } \\
\text { Thomas Cook Group Limited and Interpayment Services Limited } \\
\text { (1995) } \\
\text { Nutricia Holdings Ltd and Valio International UK Ltd: (1995) } \\
\text { NV Verenigde Bedrijven Nutricia and enterprises belonging to } \\
\text { Milupa AG (1996) } \\
\text { Bass PLC, Carlsberg A/S and Carlsberg-Tetley PLC (1997) } \\
\text { FirstBus plc and S B Holdings Limited (1997) } \\
\text { ARRIVA plc and Lutonian Buses Ltd (1998) } \\
\text { British Sky Broadcasting Group plc and Manchester United PLC } \\
\text { (1999) }\end{array}$ & 1 & $\begin{array}{l}\text { NTL Incorporated and Cable \& } \\
\text { Wireless Communications plc } \\
\text { (2000) } \\
\text { Nutreco Holding NV and Hydro } \\
\text { Seafood GSP Ltd (2000) } \\
\text { Lloyds TSB Group plc and Abbey } \\
\text { National plc (2001) } \\
\text { Compass Group PLC and Rail } \\
\text { Gourmet Holding AG, Restorama } \\
\text { AG and Gourmet Nova AG } \\
\text { (2002) } \\
\text { Safeway plc and Asda Group } \\
\text { Limited (owned by Wal-Mart } \\
\text { Stores Inc); Wm Morrison, } \\
\text { Sainsbury and Tesco (2003) } \\
\text { Serviced Dispense Equipment } \\
\text { Limited and the Technical } \\
\text { Services function of Coors } \\
\text { (2005) } \\
\text { HJ Heinz and HP Foods (2006) }\end{array}$ \\
\hline
\end{tabular}

